\title{
MENINGKATKAN KESAN POSITIF PEMBACA TEKS PAKET PERJALANAN WISATA MELALUI KONJUNGSI
}

\author{
I Gusti Ngurah Adi Rajistha \\ Universitas Warmadewa \\ rajistha@warmadewa.ac.id \\ Made Detrichyeni Winaya \\ Universitas Warmadewa \\ made.detrichyeni.winaya@gmail.com
}

\begin{abstract}
ABSTRAK
Memberikan kesan positif pada teks yang dibuat merupakan hal mendasar agar pembaca betah membaca teks yang disajikan. Namun tidak semua penulis dapat membuat teks yang dapat memberikan kesan positif tersebut. Penerapan kohesi gramatikal, khususnya konjungsi, merupakan salah satu cara yang dapat diterapkan untuk mengurangi tingkat perpindahan pembaca ke situs website lain. Tujuan dari penelitian ini adalah untuk memberikan gambaran umum penggunaan konjungsi pada teks paket perjalanan wisata melalui makna semantis yang disajikan oleh keempat jenis konjungsi tersebut. Data dari penelitian ini adalah 41 teks paket perjalanan wisata yang diambil dalam bentuk *.txt dari website ganggabali.com. Data dari penelitian ini dianalisis menggunakan teori kohesi gramatikal oleh Halliday dan Hasan (1976). Hasil analisis data disajikan secara formal dan informal. Penelitian ini menunjukkan bahwa semua jenis konjungsi telah digunakan untuk memberikan makna semantis antar kalimat pada teks paket perjalanan wisata. Penggunaan konjungsi ini, di luar faktor yang lain, dapat memberikan kesan positif bagi pembaca karena melalui penggunaan konjungsi, pemilik website mampu memberikan relasi semantis sesuai dengan jenis konjungsi yang digunakan.
\end{abstract}

Kata kunci: bounce rate; konjungsi; relasi semantis; teks website

\section{ABSTRACT}

Giving a positive impression in the text made is a basic thing to do in order to make readers feel comfortable reading texts given. However, not all writers can make texts that can express a positive impression. Application of grammatical cohesion, especially conjunction, is one of some ways that can be applied to reduce bounce rate to other websites. The aim of this research is to give a general overview of using conjunction in tour package texts by conveying semantic relation provided by all kinds of conjunctions. The data of this research were 41 tour package texts taken in the form of *t.txt from a website named ganggabali.com. The data of this research were analyzed by applying the grammatical cohesion theory proposed by Halliday and Hasan (1976). The result of the analysis was presented by using formal and informal methods. This research shows all kinds of conjunction were applied to convey semantic relations among sentences in tour package texts. The use of the conjunctions, excluding other factors, can give readers a positive impression because by using conjunctions, the website owner can convey the semantic relation based on the kinds of conjunction applied.

Keywords: bounce rate; conjunction; semantic relation; website text

\section{PENDAHULUAN}

Website merupakan salah satu media promosi yang berkaitan erat dengan internet.
Website juga dapat digunakan sebagai media untuk mengiklankan produk yang dimiliki (Salehi \& Farahbakhsh, 2014). Dengan 
memiliki website, suatu unit usaha dapat dikenal secara luas karena dapat diakses secara daring. Melalui website, ruang lingkup usaha menjadi sangat luas dan tidak terbatas. Dari populasi dunia sebesar 7.676 milyar, 4.388 milyar penduduk dunia telah mengenal internet (Kemp, 2019). Hal ini menunjukkan bahwa internet telah menjangkau lebih dari setengah populasi dunia. Dengan demikian, penggunaan website sebagai sarana promosi produk atau jasa disamping gencarnya promosi melalui sosial media merupakan cara yang tepat untuk memperkenalkan produk dan jasa yang ditawarkan.

Sebagai media promosi, bahasa dapat dikatakan sebagai bagian yang sangat mendasar dan penting. Bahasa yang digunakan jelas didukung dari segi visual berupa penggunaan gambar, audio, atau bahkan video yang relevan. Dalam hal ini, untuk membentuk kohesi dalam website tidak hanya menggunakan konten yang berupa teks tetapi juga konten yang berupa gambar dan audio (Schiller, 2008).

Bahasa sebagai elemen dasar pada website hendaknya dapat menyampaikan makna persuasif. Makna persuasif dapat dibentuk dengan menerapkan konsep koherensi melalui penggunaan penanda kohesi. Semakin banyak penggunaan penanda kohesi dan koherensi maka semakin fokus pada subjek yang dibicarakan pada level tekstual sehingga penanda tersebut memberikan makna persuasif pada para pembaca (Flergin, 2014). Secara sederhana, koherensi membantu pemilik teks dalam membentuk makna persuasif. Disamping itu, perlu diperhatikan bahwa selalu terdapat hubungan antara discourse dan word choices (Paltridge, 2006).

Koherensi dapat dibentuk secara gramatikal maupun secara leksikal. Secara gramatikal, koherensi diklasifikasikan menjadi acuan, substitusi, elipsis, konjungsi, sedangkan secara leksikal, koherensi dapat diklasifikasikan menjadi reiteration dan collocation (Halliday \& Hasan, 1976). Dengan demikian, konten website dibangun dan disusun sendiri oleh penulis website tersebut sehingga makna teks tersebut sepenuhnya dikontrol oleh pembuat teks (Degano, 2014). Dalm hal ini, pembuat teks memiliki kuasa penuh tentang arah teks yang dibuat. Namun demikian, pembuat teks harus tetap berpegang teguh terhadap koherensi pada teks yang dibuat. Salah satu jenis koherensi yang dibahas pada penelitian ini adalah koherensi secara gramatikal, yaitu konjungsi.

Dilihat dari segi praktis, koherensi secara leksikal lebih berpengaruh terhadap perkembangan website dibandingkan dengan koherensi secara gramatikal. Hal ini dapat diketahui dari penerapan reiteration dan collocation pada konten website yang berkaitan hingga pada aspek internal website (Rajistha, Claria, Warmadewi, \& Susanthi, 2018). Namun mekipun demikian, koherensi secara gramatikal tidak bisa dipandang tidak memberikan dampak terhadap perkembangan website. koherensi secara gramatikal dapat memberikan kesan positif pada pembaca untuk mengurangi bounce rate.

Penelitian ini mengungkap penggunaan konjungsi untuk memberikan makna semantis antar bagian dalam teks website biro perjalanan wisata. Melalui penelitian ini, penulis memberikan gambaran umum pengaruh konjungsi dalam memberikan makna kohesi untuk meningkatkan kesan positif dari pembaca sekaligus mengurangi lompatan (bounce) yang dilakukan oleh pengunjung website.

\section{METODE}

Penelitian ini merupakan penelitian deskriptif kualitatif. Sumber data penelitian ini adalah teks-teks paket perjalanan wisata pada situs ganggabali.com. Data penelitian ini adalah 41 teks paket perjalanan wisata. Teks tersebut diperoleh melalui kerjasama dengan web developer. Data dikumpulkan dalam format *.txt untuk mempermudah pengolahan data menggunakan aplikasi korpus data antconc. Melalui penggunaan aplikasi korpus tersebut, data dapat dikumpulkan secara lebih cepat. Penggunaan google drive juga sangat membantu dalam membagi data dan tugas dalam penelitian ini. Teori yang digunakan dalam penelitian ini adalah teori kohesi oleh Halliday dan Hasan (1976). Data yang telah dikumpulkan dikategorikan sesuai dengan jenis konjungsi berdasarkan teori tersebut, additive, adversative, causal, dan temporal. Hasil analisis data disajikan secara formal untuk mempermudah dalam memberikan gambaran umum hasil penelitian dan secara informal untuk mendeskripsikan hasil temuan. 


\section{PEMBAHASAN}

Konjungsi berbeda dengan ketiga jenis kohesi seperti acuan, substitusi dan elipsis. Konjungsi tidak menjelaskan acuan atau substitusi dari item dalam kalimat melainkan mengindikasikan relasi semantis antar elemen yang membentuk teks. Jenis ini dapat diklasifikasikan menjadi additive, adversative, causal dan temporal. Additive merupakan konjungsi yang memberikan tanda adanya informasi tambahan seperti pada contoh (1). Adversative adalah konjungsi yang memberikan tanda adanya informasi yang bertentangan seperti pada contoh (2). Causal mengindikasikan relasi semantis berupa hasil, tujuan atau alasan seperti pada contoh (3). Sedangkan temporal mengindikasikan relasi semantis dalam rangaian waktu tertentu seperti pada contoh (4).

1) Perhaps she missed her train. Or else she's changed her mind and isn't coming. (Halliday \& Hasan, 1976)

2) She failed. However, she's tried her best. (Halliday \& Hasan, 1976)

3) You aren't living, are you? Because I've got something to say to you. (Halliday \& Hasan, 1976)

4) Brick tea is a blend that has been compressed into a cake. It is taken mainly by the minority groups in China. First, it is ground to a dust. Then it is usually cooked in milk. (Nunan, 1993)

Jenis ini memberikan makna koherensi pada teks melalui kata penghubung. Pada umumnya kata penghubung dapat dibedakan menjadi beberapa jenis sesuai dengan kegunaannya dalam menghubungkan klausa ataupun kalimat. Pada pembahasan ini, konjungsi yang dimaksud dalam teks adalah konjungsi yang dapat memberikan makna additive (tambahan), adversative (bertentangan), causal (alasan), dan temporal (hubungan waktu). Melalui penggunaan konjungsi, makna antara kalimat yang satu dengan kalimat yang lainnya dapat diketahui baik itu makna sebab akibat ataupun makna yang lainnya. Berdasarkan sumber data, keempat jenis konjungsi ini digunakan oleh pemilik website untuk memberikan makna koherensi antar kalimat. Berikut ini merupakan tabel yang menyajikan penggunaan konjungsi pada teks paket perjalanan wisata pada sumber data.

Tabel 1 Konjungsi dalam Teks Paket Perjalanan Wisata

\begin{tabular}{lll}
\hline No. & $\begin{array}{l}\text { Jenis } \\
\text { Konjungsi }\end{array}$ & $\begin{array}{l}\text { Konjungsi yang } \\
\text { Digunakan } \\
\text { besides, or, and, in } \\
\text { addition }\end{array}$ \\
\hline 1 & Additive & but \\
\hline 2 & Adversative & because, so \\
\hline 3 & Causal & then, next, after that \\
\hline 4 & Temporal
\end{tabular}

\section{Additive}

Dilihat dari makna kata additive sudah dapat diketahui bahwa conjunction jenis ini memberikan makna tambahan terhadap kalimat yang sebelumnya. Namun jenis ini tidak hanya digunakan untuk memberikan makna tambahan tetapi dapat juga digunakan untuk memberikan pilihan alternatif. Berdasarkan data yang telah dikumpulkan, pemilik website hanya menerapkan beberapa jenis conjunction ini. Berikut ini adalah data-data yang menunjukkan makna additive:

1. Bali has many beautiful beaches, one of which is the Blue Lagoon Beach Bali. Besides having a beautiful beach, Blue Lagoon Beach Bali has an underwater beauty that is unrivaled. (Gusti, Made, \& Naya, n.d.-a)

2. During a vacation in Bali, of course, you feel tired caused by a long trip to Bali. Or you are tired of traveling all day to visit various tourist attractions in Bali. (Gusti, Made, \& Naya, n.d.-d)

3. See dolphins under the beautiful sunrise on Lovina beach, relax at Banjar Natural Hot Spring, and Munduk Waterfall is some of the destinations we will visit. And there are several other interesting destinations to be visited. (Gusti, Made, \& Naya, n.d.g)

4. As a bonus tour, we will invite you to visit the fruit and vegetable market in Bedugul. You can buy fresh vegetables and fruits here. In addition, we will also invite you to a coffee plantation to see traditional coffee processing and you can also try tasting free coffee and tea here. (Gusti et al., n.d.-g) 


\section{MENINGKATKAN KESAN POSITIF PEMBACA TEKS ...}

Pada data (1), konjungsi yang digunakan adalah besides. Konjungsi ini memberikan informasi tambahan terhadap hal yang disampaikan pada kalimat sebelumnya. Pemilik website ingin menyampaikan bahwa terdapat dua hal yang berhubungan yang dapat ditemukan jika berkunjung ke obyek wisata tersebut. Dalam hal ini, penggunaan konjungsi ini memberikan hubungan yang menciptakan koherensi antar klausa atau kalimat. Jadi hubungan makna antar klausa atau kalimat dapat diketahui secara jelas.

Data (2) menunjukkan penggunaan or untuk memberikan informasi alternatif. Berdasarkan data, pemilik website berspekulasi tentang dua hal yang berbeda namun berhubungan berdasarkan konteks yang dibicarakan. Dalam hal ini, pemilik berspekulasi bahwa wisatawan pasti akan merasakan kelelahan. Berdasarkan spekulasi tersebut, pemilik website berpendapat tentang dua hal yang mungkin menyebabkan hal tersebut dengan menggunakan or untuk memberikan alternatif penyebab kelelahan yang mungkin dirasakan oleh wisatawan.

Data (3) dan (4) menunjukkan penggunaan and dan in addition untuk memberikan informasi tambahan terhadap kalimat yang dinyatakan sebelumnya. Pada data (3), and digunakan untuk memberikan informasi tambahan tentang tempat wisata lain yang akan dikunjungi. And pada dasarnya merupakan coordinating conjunction yang digunakan untuk menghubungkan dua klausa independen yang setara dan membentuk kalimat majemuk setara. Namun dilihat dari sudut pandang analisis diskursus, and sering digunakan sebagai penghubung kalimat, sentence transition. Berbeda halnya dengan data (3), data (4) menunjukkan penggunaan penghubung kalimat, in addition, untuk menghubungkan dua kalimat yang memiliki relasi makna. Dalam hal ini, kalimat kedua merupakan informasi tambahan terhadap apa yang telah dijelaskan pada kalimat pertama.

Penggunaan additive dapat dikatakan sebagai cara lain untuk membangun koherensi dalam teks. Dengan menerapkan jenis konjungsi ini, pemilik website dapat menyampaikan banyak hal untuk memperkaya informasi yang ingin disampaikan sehingga pembaca website atau pelanggan website dapat memperoleh informasi yang cukup sebelum memutuskan untuk memilih paket wisata yang sesuai. Jadi secara sederhana additive digunakan untuk memperkaya informasi pada teks dengan memberikan informasi tambahan atau informasi alternatif.

\section{Adversative}

Adversative merupakan konjungsi yang menyatakan makna bertentangan dengan ekspektasi. Konjungsi ini biasanya ditandai dengan penggunaan but, yet, though dll. Berdasarkan sumber data, hanya ditemukan satu data yang menunjukkan penggunaan konjungsi adversatif. Berikut ini adalah data tersebut.

After visiting a coffee plantation, the trip will continue to Ulun Danu Temple in Bedugul. But beforehand, we will invite you to lunch at one of the restaurants near the Ulun Danu Temple. (Gusti, Made, \& Naya, n.d.-h)

Pada data tersebut jelas bahwa pada kalimat ditemukan penggunaan but beforehand yang menandakan makna bertentangan dengan ekspektasi. Hal yang dipertentangkan di sini adalah kronologis kegiatan yang dilakukan apabila memilih paket ini. Kegiatan yang dilakukan pada paket wisata ini disusun secara tidak kronologis. Di sini konjungsi adversative digunakan untuk memberikan gaya penulisan yang lebih menarik dan tentunya memberikan koherensi antar kalimat. Koherensi tersebut terjadi antara kalimat yang menggunakan konjungsi adversatif dengan kalimat sebelumnya. Dengan kata lain, kedua kalimat tersebut berhubungan satu dengan yang lainnya melalui konjungsi ini.

Penggunaan konjungsi jenis ini memberikan koherensi melalui makna yang bertentangan. Meskipun jenis ini hanya digunakan satu kali namun dapat dinyatakan bahwa koherensi juga terbentuk dengan mempertentangkan makna. Seperti data di atas, hal yang dipertentangkan adalah kronologi kegiatan yang dilakukan. Kegiatan yang dilakukan dalam paket perjalanan wisata tersebut tidak disajikan secara kronologis sehingga penggunaan konjungsi adversative jelas memberikan makna koheren pada kedua kalimat tersebut. 


\section{Causal}

Jenis konjungsi ini digunakan untuk memberikan makna sebab atau untuk menyatakan hasil dari suatu kegiatan. Berdasarkan sumber data, pemilik website hanya menerapkan beberapa jenis konjungsi ini. Berikut ini adalah data yang ditemukan pada sumber data.

1. Why cheap? Because we collaborate with the manager of Ayung River Rafting and Telaga Waja Rafting so you don't have to worry about the quality of the services we provide. (Gusti, Made, \& Naya, n.d.-c)

2. We will always follow you with the private car that you ordered along the way from the starting point to the finish point of Kintamani Cycling activities. So you do not have to worry if you feel that you are not strong enough to continue Kintamani Cycling activities, because we are always there for you. (Gusti, Made, \& Naya, n.d.-f)

Pada data (1), because digunakan untuk memberikan alasan terhadap pernyataan sebelumnya yang disampaikan oleh pemilik website. Pemilik website menyatakan alasan dari pertanyaan yang diutarakannya sebelumnya. Because merupakan subordinator yang biasanya digunakan untuk membentuk klausa dependen sehingga dapat dikombinasikan dengan klausa independen dalam membentuk kalimat kompleks. Jika diperhatikan lagi secara sintaksis, struktur kalimat tersebut tidak berterima. Namun dilihat dari sudut pandang analisis diskursus, penggunaan tersebut dapat berterima. Hal ini diterapkan oleh pemilik website untuk menarik pembaca atau pengunjung website untuk memesan paket wisata yang ditawarkan.

Data (2) menunjukkan penggunaan so yang menyatakan hasil atau simpulan dari hal yang disampaikan sebelumnya. Sama seperti coordinating conjunction yang lainnya, so digunakan untuk menghubungkan dua klausa independen untuk membentuk kalimat majemuk setara. Namun pada data tersebut, so digunakan pada awal kalimat. Secara analisis diskursus penggunaan so dapat berterima sebagai penanda causal yang menyatakan simpulan dari kalimat sebelumnya. Dalam hal ini, pemilik website menyampaikan simpulan yang dimaksudkan dari kalimat yang pertama.

Berdasarkan analisis tentang konjungsi yang menyatakan causal dapat diketahui bahwa pemilik website tidak terlalu sering menggunakan jenis konjungsi ini untuk memberikan makna koherensi antar klausa atau kalimat. Penggunaan konjungsi ini hanya digunakan oleh pemilik untuk menyatakan simpulan dari suatu pernyataan dan untuk menyampaikan alasan tentang suatu hal.

\section{Temporal}

Konjungsi ini digunakan untuk menyatakan informasi waktu dari suatu kegiatan yang dinyatakan di dalam kalimat. Dengan menggunakan jenis konjungsi ini, kegiatankegiatan yang ditawarkan dalam suatu paket dapat disajikan sesuai dengan organisasi waktu tertentu sehingga mempermudah pembaca atau pengunjung website untuk mengetahui runtutan kegiatan. Berdasarkan sumber data, berikut ini adalah data-data yang menunjukkan penggunaan penanda konjungsi temporal.

1. At Celuk Village we will find many gold and silver craftsmen with various types of artwork made of gold or silver. Then in Batuan Village, we will visit a village famous for its paintings. (Gusti, Made, \& Naya, n.d.-i)

2. Are you interested in this Bali Full Day Tour package? Next, we summarize the tour plan that we will get in this package. (Gusti, Made, \& Naya, n.d.-e)

3. You will be given information about safety standards and other information about the cycling activities you will do. After that, you will be given a bicycle that matches your posture or according to your wishes. (Gusti, Made, \& Naya, n.d.-b)

Pada data (1), then merupakan penanda temporal yang digunakan untuk menyatakan bahwa kegiatan yang dimaksud pada kalimat ini adalah kegiatan yang dilakukan setelah kegiatan pada kalimat sebelumnya dilakukan. Dengan menggunakan then, pemilik website dapat menjelaskan kegiatan-kegiatan yang dilakukan secara kronologis. Then memberikan makna koherensi di dalam teks dengan menghubungkan kalimat-kalimat melalui makna yang kronologis. 
Tidak berbeda jauh dengan data (1), data (2) dan (3) juga merupakan penanda temporal yang digunakan di dalam teks. Dapat diketahui bahwa next pada data (2) dan after that pada data (3) memiliki makna yang sama. Kedua penanda temporal ini juga membuat teks menjadi koheren melalui hubungan makna kronologis. Jadi antar kalimat dapat dilihat hubungannya dalam hubungan waktu tertentu.

Penggunaan penanda-penanda temporal pada teks biro perjalanan wisata sangat membantu pembaca atau pengunjung website untuk mengetahui alur kegiatan yang ditawarkan karena disampaikan secara kronologis. Koherensi melalui penggunaan konjungsi dapat memberikan kesan positif dalam membaca suatu paket perjalanan wisata. Urutan waktu yang disampaikan secara jelas dengan menyematkan jenis konjungsi ini tentu langkah yang tepat mengingat teks yang dibuat merupakan paket perjalanan wisata yang menyajikan kegiatan-kegiatan wisata secara kronologis.

\section{SIMPULAN}

Berdasarkan hasil analisis di atas dapat disimpulkan bahwa penggunaan konjungsi meruapakan cara untuk memberikan makna semantis antar kalimat dalam teks. Hasil ini jelas sesuai dengan teori kohesi Halliday dan Hasan (1976). Berdasarkan hasil penelitian, beberapa jenis konjungsi yang tergolong sebagai coordinating conjunction, yang biasanya digunakan sebagai konjungsi untuk membentuk kalimat majemuk setara, digunakan sebagai konjungsi yang memberikan makna koherensi. Penerapan keempat jenis konjungsi tersebut jelas mengindikasikan relasi semantis yang memberikan kesan koherensi, baik memberikan makna tambahan, bertentangan, sebab akibat, ataupun makna kronologis. Hal ini jelas mampu menimbulkan kesan positif bagi pembaca dan dapat mengurangi bounce rate dilihat dari segi penggunaan bahasa. Namun hal ini tidak dapat dijadikan patokan dasar karena selalu ada faktor lain yang menunjang kesetiaan pembaca dalam membaca suatu teks paket perjalanan wisata, seperti harga, layanan, ulasan pada situs review, dll.

\section{DAFTAR PUSTAKA}

Degano, C. (2014). Textuality on the web: A focus on argumentative text types. IGI Global, 414-436.

Flergin, A. (2014). Language of persuasion: A discourse approach to advertising language. Research Journal of Recent Sciences, 3, 62-68.

Gusti, Made, G., \& Naya, K. (n.d.-a). Activity: Blue Lagoon Snorkeling Bali. Retrieved March 30, 2019, from https://ganggabali.com/packages/activitie s-and-adventuretour/5ba1b9ff082ab/blue-lagoonsnorkeling-package

Gusti, Made, G., \& Naya, K. (n.d.-b). Activity: Kintamani Cycling Tour. Retrieved March 30, 2019, from https://ganggabali.com/packages/activitie s-and-adventuretour/5bcac7d9611c1/activity-kintamanicycling-tour

Gusti, Made, G., \& Naya, K. (n.d.-c). Adventure: Big Discount for Bali Rafting Adventure. Retrieved March 30, 2019, from

https://ganggabali.com/packages/activitie s-and-adventuretour/5bb4714d5290f/adventure-bigdiscount-for-bali-rafting-adventure

Gusti, Made, G., \& Naya, K. (n.d.-d). Bali SPA: Balinese Massage \& SPA in Jimbaran. Retrieved March 30, 2019, from https://ganggabali.com/packages/balispa/5bc4ac8e03bd7/bali-spa-balinesemassage-spa-in-jimbaran

Gusti, Made, G., \& Naya, K. (n.d.-e). Full Day: Bali Quad Bike Adventure, Hot Spring, Tegalalang Rice Terrace (Swing), Coffee Plantation. Retrieved March 30, 2019, from

https://ganggabali.com/packages/balifull-day-tours/5bf4e5632bff7/full-daybali-quad-bike-adventure-hot-springtegalalang-rice-terrace-swing-coffeeplantation

Gusti, Made, G., \& Naya, K. (n.d.-f). Full Day: Kintamani Cycling, Ubud Monkey Forest, Tegenungan Waterfall. Retrieved March 30, 2019, from https://ganggabali.com/packages/balifull-day-tours/5bd0459c34ffa/full-day- 
kintamani-cycling-ubud-monkey-foresttegenungan-waterfall-tegenunganwaterfall

Gusti, Made, G., \& Naya, K. (n.d.-g). Full Day: Lovina Dolphin, Banjar Hot Sping, Buddhist Temple, Munduk Waterfall, Ulun Danu Temple. Retrieved March 30, 2019 ,

from

https://ganggabali.com/packages/balifull-day-tours/5c009d6774d3d/full-daylovina-dolphin-banjar-hot-spingbuddhist-temple-munduk-waterfall-ulundanu-temple

Gusti, Made, G., \& Naya, K. (n.d.-h). Full Day: Taman Ayun Temple, Ulun Danu Temple, Jatiluwih Rice Terrace, Tanah Lot Sunset. Retrieved March 30, 2019, from https://ganggabali.com/packages/balifull-day-tours/5c160c6538a55/full-daytaman-ayun-temple-ulun-danu-templejatiluwih-rice-terrace-tanah-lot-sunset

Gusti, Made, G., \& Naya, K. (n.d.-i). Half Day: Ubud Art Village, Taman Ayun Temple, Ubud Monkey Forest, Tanah Lot Sunset Dinner. Retrieved March 30, 2019, from https://ganggabali.com/packages/balihalf-day-tours/5be $8 \mathrm{~b} 073 \mathrm{~d} 5 \mathrm{cac} / \mathrm{half}$-dayubud-art-village-taman-ayun-templeubud-monkey-forest-tanah-lot-sunsetdinner
Halliday, M. A. K., \& Hasan, R. (1976). Cohesion in english. London: Longman Group Ltd.

Kemp, S. (2019). Digital 2019: Global internet use accelerates. Retrieved March 4, 2019, from https://wearesocial.com/blog/2019/01/dig ital-2019-global-internet-use-accelerates

Nunan, D. (1993). Discourse Analysis. London: Penguin English.

Paltridge, B. (2006). Discourse Analysis. New York: Continuum.

Rajistha, I. G. N. A., Claria, D. A. K., Warmadewi, A. A. I. M., \& Susanthi, I. G. A. A. D. (2018). Keywords, lexical cohesive devices and the impact of search engine result for tour website. In Proceedings of International Conference of Social Science, ICOSS 2018. EAI. https://doi.org/10.4108/eai.21-92018.2281128

Salehi, H., \& Farahbakhsh, M. (2014). Tourism advertisement management and efective tools in tourism industry. International Journal of Geography and Geology, 3(10), 124-134.

Schiller, A. (2008). Aspects of cohesion in web site translation: A translator's perspective. Dublin City University. 